ROCZNIKI HUMANISTYCZNE

Tom LXVIII, zeszyt 8 - 2020

DOI: http://dx.doi.org/10.18290/rh.20688-5

ANDRZEJ MARYNIARCZYK

\title{
FROM STANDARDIZATION \\ TO ABSTRACTIONALIZATION OF LANGUAGE: PROBLEMS ARISING IN TRANSLATING REALISTIC METAPHYSICS TEXTS
}

\author{
My point is, may the flexible tongue, \\ Phrase everything the head will think of - \\ Let it be, at times, as lightning bright and swift, \\ Or sad as a song of steppes, \\ Or soft as a nymph's complaint, \\ Or beautiful as the angels' speech, \\ Piercing through the spirits, all of them, in flight - \\ Each stanza must be music, not a bridle in your mouth. \\ - Juliusz Słowacki, Beniowski

\begin{abstract}
FROM STANDARDIZATION TO ABSTRACTIONALIZATION
OF LANGUAGE: PROBLEMS ARISING IN TRANSLATING
\end{abstract} \\ REALISTIC METAPHYSICS TEXTS
}

Abstract

In the process of translation of philosophical texts, especially those concerning realistic metaphysics, a complication arises, which ultimately determines the meaning of words and whole sentences. This gives rise to the problem-related triad, namely: standardization of vocabulary, abstractionalization of terms, and fragmentation of the functions of language. Standardization of language manifests itself in the fact that, instead of rich and diverse synonyms a single term appears, with which diverse processes and actions are named. Abstractionalization of language, in turn, is that language arrests our cognitive attention at terms and concepts, and compels us to analyze them. Fragmentation of the language functions consists in the breaking up of their threefold unity: semantic, syntactic, and pragmatic, and focusing instead on a single one of them: either semantic (concerning sense), or syntactic (concerning structure), or pragmatic (concerning usefulness).

Prof. Dr. habil. Andrzej MaryniarczyK, S.D.B. - The John Paul II Catholic University of Lublin, Faculty of Philosophy, Department of Metaphysics; e-mail: andrzej. maryniarczyk@ kul.pl. ORCID: https://orcid.org/0000-0001-6535-5089. 
This triad is directly linked to the processes of translation of original metaphysical texts into foreign languages, and the resulting issues are discussed in this article. Of course, this triad represents current language trends encountered in various areas. However, in the field of translating the language of realistic philosophy, i.e. metaphysics that has real things as its object, the cognitive "seeing" of that object should be guided by language.

Key words: language; realistic metaphysics; translations; language standardization; language abstractionalization; language functions

The triad: thing-concept-language indicates the specificity of the cognitive process in metaphysics and forms the basis of the answer to the question about the source and cause of the language in which we communicate our cognitive results. The answer is that our cognitive process begins with contact with a thing and ends with verbalization of this cognitive process in language. In the process of cognition, the intellect actualizes itself as a cognitive power through contact with the real thing, and, as a result of this, we obtain an intangible image of the thing, a concept that is in turn expressed in a word (name). The very process of cognition is carried out in the predicative judgments of the type "John is human" or "John is not human," and is an operation on concepts, consisting in combining or disconnecting them (more on this in Krąpiec $44 \mathrm{ff}$.).

The second triad, namely: syntactic-semantic-pragmatic, concerns the function of language (Krapiec $10 \mathrm{ff}$.). This triple function of language is indispensable for communicating the results of metaphysical (realistic) cognition. It is here, at this level of language analysis - when the translation into another language commences and the syntactic side of language is being modified - that a complication occurs, which ultimately determines the meaning of words and whole sentences. This gives rise to the third triad, which concerns our problem area, as it is directly related to translations of original texts into foreign languages, namely: standardization of vocabulary, abstractionalization of terms, and fragmentation ${ }^{1}$ of the functions of language.

Of course, these are general language trends that we encounter in different areas. However, in the field of the language of realistic philosophy (that is: metaphysics which has real things as its object), the cognitive "seeing" of things should be directed by language.

\footnotetext{
${ }^{1}$ Pol. 'parcelaryzacja'. This original, Polish term retains the full meaning of the French parcellizer (v. "to divide up"), resulting in parcellaire (adj. "piecemeal," "fragmented," "individually separated"), and parcellation (n. "fragmentation").
} 


\section{STANDARDIZATION OF LANGUAGE IN TRANSLATIONS}

The dissemination of automatic translators entails the inevitable trend to standardize the language. It shows in the fact that, instead of numerous synonyms, there is one term with which diverse processes or activities are expressed. Let us take three words as examples: the first is the word "to give birth" (Polish: 'rodzić). This term is extended to embrace the entirety of new organisms being formed. Hence we say that a cat, or a dog is given birth to, also grain is given birth to, a horse, and a human being too. Meanwhile, the non-standard, natural Polish language, rich in synonyms, has a different term for each of these events. And so: a kitten is "kittened," a dog is "puppied," a horse is "foaled," grain is "pouring," and man (and only man) is born. The same goes for the (Polish) word "to produce," with which we now tend to refer to all things we successfully acquire or accomplish: a worker produces cars, a miner produces coal, but also a farmer produces grain and pigs, and a family produces offspring. Hence we even began to speak of "human resources," just like we used to talk about coal resources and their management. The same applies to the word "to love," as I can say that I love food, I love a good night's sleep, I love to walk, and I love Ann, or John, etc.

I would like to cite one example of a translation problem concerning philosophical texts, and resulting from the standardization of language. This example concerns the English translation of Karol Wojtyła's book Considerations on the Essence of Man. ${ }^{2}$ The translator wanted to express Polish words 'poznawac', 'poznanie', and 'wiedza' with the English terms "to know," "knowing," and "knowledge," arguing that such are their standard translations in American English. But, in the philosophical language, there is a clear distinction between the process of acquiring some knowledge (the Polish 'poznawać') - which should be expressed by the English terms "to cognize" / "cognizing"- and the result of this process, which is properly expressed by the terms "cognition" and "knowledge. In the English translations, however, we often come across passages where these different terms ('poznawać' / 'poznanie' and 'wiedzieć', and sometimes even 'myśleć') are reduced to the terms "to know" and "knowledge."

\footnotetext{
${ }^{2}$ Karol Wojtyła, Considerations on the Essence of Man. Rozważania o istocie czlowieka, trans. John Grondelski, Polskie Towarzystwo Tomasza z Akwinu, 2016.

${ }^{3}$ The discussion with the translator was very lively and tough, sometimes on the verge of not publishing the translation at all. However, in the end, he was persuaded that the arguments put forward were justified. See Annex.
} 
Where do these reductions and simplifications come from? One source is the abovementioned language standardization, advancing with automatic translators and new editions of dictionaries. The second source may be the lack of philosophical specialization of those who do the translations. These people did not specialize in "hard philosophy," i.e., the philosophy of being or metaphysics / philosophy of cognition, where the word "to cognize" is universally accepted. Sometimes, specialists in "soft" philosophical fields such as philosophy of culture or art do not attach as much importance to preserving strictly philosophical terminology as specialists in "hard philosophy" do. For this reason, certainly, the phrase 'podmiot poznajacy' cannot be translated as "knowing subject," as this deforms the content of the expression. This is a "cognizing subject," and nothing else. No wonder that the translators of Summa Theologiae of St. Thomas Aquinas (part I. q. 75-89), who were educated in the philosophy of being and metaphysics of cognition, instead of "to know an object" translated the original terms correctly as "to cognize an object." After a prolonged discussion with the translator, these "prevarications" were eventually avoided in the published translation of Karol Wojtyła's Considerations on the Essence of Man. However, they were not avoided in the translation of Karol Wojtyła's basic work Osoba i czyn. The translation of the title itself: The Acting Person (instead of Person and $A c t$ ) is misleading for the reader. The author's intention was to show the subjectivity (personality) of a human being, which is revealed in the act, and actualized through the act, and not to give a presentation of the phenomenon of a person's action. ${ }^{4}$

On the one hand, language standardization is necessary for the preparation of foreign language dictionaries. On the other hand, however, it prevents the language from guiding us to see things.

\section{ABSTRACTIONALIZATION OF LANGUAGE IN TRANSLATIONS}

The second problem is the abstractionalization of language. It is manifested in the fact that language keeps our cognitive attention on terms and concepts and directs us towards analyses of these terms or concepts. And so we deal with the analysis of a concept (or term) such as 'man,' 'being,'

\footnotetext{
${ }^{4}$ It is worth getting acquainted with the article by Jałocho-Palicka (155-188) on the English translation of the basic work by Karol Wojtyła Osoba i czyn.
} 
'cell,' 'person,' etc. However, the goal of the language of realistic philosophy (metaphysics, the theory of being) is to guide us to see things such as [really existing] men, beings, cells, persons, etc.

This shift of language one level up makes us cultivate meta-metaphysics instead of metaphysics, meta-biology instead of biology, etc. This means that, instead of getting to know the world of things, we analyze concepts, or terms, in which this or that way of cognizing the world was expressed. How far removed from the awareness of this deformation some translators can be, becomes clear when we examine, as an example, the translation of two passages from Aristotle's Metaphysics into Polish as well as into other languages. $^{5}$

The first of these passages comes from the beginning of Book IV of Metaphysics, where Aristotle presents how the subject of metaphysics is understood. Stagyrite writes there: „Tò $\delta \dot{\varepsilon}$ òv $\lambda \dot{\varepsilon} \gamma \varepsilon \tau \alpha \mu l \mu \grave{\varepsilon} v \pi \mathrm{o} \lambda \lambda \alpha \chi \tilde{\omega} \varsigma$ [to de on légetai men pollachōs] [...]." " In William of Moerbeke's Latin translation, this text was rendered correctly, in the same spirit. We read there: "Ens autem multis quidem dicitur modis..."7 This means that Aristotle announces: "Being is understood (recognized/predicated) in many different ways." 8 Thus, metaphysics is supposed to deal with being, but being is spoken of in a variety of ways (as a tree that grows over there, as John with whom I talk, as a color (accident) that I discern, as friendship (a relation) that I am in, etc.). Meanwhile, let us see what happened in translations into modern languages.

In the renowned English translation of Aristotle's complete works, published in a bilingual version by Harvard University Press, Hugh Tredennick translated this passage as follows: "The term 'being' is used in various senses, (but with reference to one central idea)..." (Aristotle, The Metaphysics 147). Thanks to the translator, instead of being, which metaphysics is supposed to deal with, the term 'being' was indicated as that which is to be investigated. The Polish translation by Kazimierz Leśniak approaches this fragment in a similar fashion: "Being' is an ambiguous concept (but it always refers to 'one' "). ${ }^{9}$ Thus, Leśniak also tells the reader that the object of

\footnotetext{
${ }^{5}$ This part of the analysis was discussed in more detail in the article Maryniarczyk, "Rola języka naturalnego" 19-21.

${ }^{6}$ See the Greek text in Arystoteles [Aristotle], Metafizyka [Metaphysics] (Krapiec et al.) 1003 a 33-35.

${ }^{7}$ Ibid., Latin text.

8 “Byt pojmuje się różnorodnie.” Ibid., Polish text.

9 “' 'Byt' jest pojęciem wieloznacznym, (ale odnosi się zawsze do 'jednego'). Arystoteles [Aristotle], Metafizyka, trans. K. Leśniak, 1003 a (p. 71).
} 
metaphysics is the analysis of the concept of being. This practice has been widely reproduced in German, French and Italian translations. No wonder, then, that "a small mistake (made by a translator) at the beginning" has become "a great one at the end." The translators led the readers (or actually led them all astray!) to an understanding of metaphysics as a science that studies the "concept of being" or the meaning of the term "being." It is as if someone, translating a text on biology, stated that biology and biologists are concerned with analyzing terms such as "life" and "cell" or the concepts of life and cell.

Another example of abstractionalization of the language of metaphysics is the translation of the Aristotelian canon of categories (Arystoteles [Aristotle], Metafizyka [Metaphysics], trans. Leśniak, 1020 a 6 - 1021 b 11; Kategorie [Categories], trans. Leśniak 40-53). Translations of Aristotle's categories are equivalents in various languages (including Polish) of terms such as: "quantity," "quality," "place," "activity," "experience," etc. However, Aristotle says that there is something that bears some quantity, quality, somewhere, for a given time, etc. Thus, Aristotle will go on to explain that:

To be, in the proper sense, is understood as indicated by different figures of predication; for there are as many ways of understanding being as many there are ways of predication. Now, since some predicates indicate what a thing is, and others what quality it is, in what quantity or relation it is, others still, that it acts or passively receives, occupies some place or takes some time, to each of these corresponds another way of being. There is no difference between "the man is healthy" and "the man feels alright"; or between "the man is walking" or "cutting" and "the man walks" or "cuts"; and similarly in the other cases. (Arystoteles [Aristotle], Metafizyka [Metaphysics], Krąiec et al. 1017 a 24-30) ${ }^{10}$

In this way, Aristotle explains and points out the "real-thing-oriented" character of the language of realistic metaphysics (philosophy). ${ }^{11}$

\footnotetext{
${ }^{10}$ This Greek, Latin, and Polish edition was referred to in establishing the new, English text above). The difference between this and the previously established, English text is quite remarkable, as Hugh Tredennick's translation went like this: "The senses of essential being are those which are indicated by the figures of predication; for «being» has as many senses as there are ways of predication. Now since some predicates indicate (a) what a thing is, and others its (b) quality, (c) quantity, (d) relation, (e) activity or passivity, (f) place, (g) time, to each of these corresponds a sense of «being.» There is no difference between «the man is recovering» and «the man recovers»; or between «the man is walking» or «cutting» and «the man walks» or «cuts»; and similarly in the other cases." Perseus.org, http://data.perseus.org/citations/ urn:cts:greekLit: tlg0086.tlg025.perseus-eng1:5.1017 a, accessed 10.01.2020.

${ }^{11}$ It is worth quoting here a passage from St. Thomas Aquinas, commenting on Aristotle's Peri Hermeneias. He wrote: "The verbs contained in the nouns [i.e., participles] and posited as subjects have the virtue of names [nouns]: therefore, in the Greek tongue and in popular Latin
} 
Only the Lublin translation of Aristotle's Metaphysics, published in a three-language version, brings closer the original meaning of the language of metaphysics and, consequently, the understanding of metaphysics itself and its proper object. In this version of the translation we will find out that, according to Aristotle, "being is conceived of in a number of different ways, but always in relation to something single." (Arystoteles [Aristotle], Metafizyka [The Metaphysics], Krąpiec et al., 1003 a 33-35). It is therefore being, and not the concept of being or the term "being," that is the object of investigations in metaphysics.

\section{FRAGMENTATION OF THE LANGUAGE FUNCTIONS IN TRANSLATIONS}

The third problem is the breaking up the unity of the triple function of language: semantic, syntactic and pragmatic, and focus on one of them: either only semantic (concerning sense), or only syntactic (concerning structure), or only pragmatic (concerning usefulness). This fact is also reflected in translations of philosophical texts (and realistic metaphysics texts in particular) into foreign languages. The dilemma faced by translators is whether to render the meaning of a sentence, or to remain faithful to syntax, or to concentrate on linguistic pragmatics and adapt the language to the contemporary reader and his intellectual capabilities.

It must be recalled, however, that there are three binding triads in realistic metaphysics for language analysis: (1) the triad of language composition: object-cognition-language, in the context of which language must be considered; (2) the triad of functions of language: semantic-syntactic-pragmatic, which cannot be broken down; (3) the triad of reference: object-languageobject. Language, together with cognition, grows out of the object, is formu-

languages (e.g. Italian or French), they have an added article to indicate their independent existence. And it is proper for a verb to signify action. An action can be signified in three ways: first, per se, in abstraction, as a thing of some kind, signified by a noun when, for example, we say «action», «sensation», «walking», «running», etc.; secondly, in the mode of an action, inasmuch as it proceeds from the substance and is inhered in it as in a subject: here, [an action] is signified by verbs in other modes [e.g., an infinitive], which are considered to be predicates. But since the process itself or the inherence of an action can be intellectually apprehended and signified as a thing of some kind, therefore [and thirdly], the verbs in the indefinite mode, which signify the inherence of an action in the subject, can be considered both as verbs (because of their "cooccurrence») and predicates (inasmuch as they signify, as it were, a thing of some kind). Thomas Aquinas, Komentarz do Peri Hermeneias [Commentary to On Interpretation], quoted in Krapiec $74 \mathrm{f}$ (translated on the basis of the Polish text). 
lated in the way in which the object exists and refers to that object. It is a real-thing-oriented language; it refers to things and leads to seeing and understanding them. ${ }^{12}$

Moreover, it should be noted that the language we use in realistic metaphysics is the first-degree language in its basics, i.e. it is the so-called objective, or real-thing-oriented language. It is similar to the language of real sciences. In real sciences we do not talk about the concept of a cell, but about a cell, not about the concept of heart, but about heart, not about the concept of bread, but about bread. In these sciences we do not analyze the concepts or terms such as "cell," "kidneym" or "heart," but we learn about these elements of the body. The same applies to the degree of metaphysical language. It is the first degree language, in which we talk about being (or beings) and not about the concept of being, about the soul, not the concept of the soul, about the person (persons), not the concept of the person, about matter, and not about the concept of it, etc.

All these issues cannot be overlooked by translators who undertake their work on texts of realistic metaphysics. These texts discuss problems, which concern both reality in general and its individual components, including in particular human beings, their actions and behavior. Otherwise (i.e. translating without full knowledge of the object of their work), they will deserve the reprimand that St. Thomas Aquinas expressed to Averroes, the great commentator and translator of Aristotle, calling him depravator potius quam interpretator ("more a depraver than an interpreter").

\section{BIBLIOGRAPHY}

Aristotle. The Metaphysics. Translated by Hugh Tredennick. Havard University Press, 1980. Arystoteles. Metafizyka. Translated by Kazimierz Leśniak, PWN, 1983.

Arystoteles. Kategorie. Translated by Kazimierz Leśniak, PWN, 1990.

Arystoteles. Metafizyka, oprac. Mieczysław A. Krąpiec \& Andrzej Maryniarczyk na podstawie tłum. Tadeusza Żeleźnika, Polskie Towarzystwo Tomasza z Akwinu, 2017.

Jałocho-Palicka, Małgorzata. „Osoba $i$ czyn - The Acting Person - ingerencje redaktorskie i problemy przekładu. Przyczynek do analizy." Wokót antropologii Karola Wojtyly. Zadania współczesnej metafizyki, nr 18, edited by Andrzej Maryniarczyk, Paulina Sulenta, and Tomasz Duma], Polskie Towarzystwo Tomasza z Akwinu, 2016, pp. 155-188.

\footnotetext{
${ }^{12}$ More on this in chap. III (“Język naturalny podmiotowo-orzecznikowy (Analiza sądów) [The Natural, Subject-Predicate Language (an analysis of judgments)]" in Krąpiec 67-99.
} 
Krąpiec, Mieczysław A. Język i świat realny. Dzieła, t. XIII. Redakcja Wydawnictw KUL, 1995. Maryniarczyk, Andrzej. „Rola języka naturalnego w metafizyce realistycznej.” Roczniki Humanistyczne, t. 59, z. 8, 2011, pp. 9-22.

Wojtyła, Karol. Considerations on the Essence of Man. Rozważania o istocie czlowieka. Translated by John Grondelski, Polskie Towarzystwo Tomasza z Akwinu, 2016.

\section{DE LA NORMALISATION À L'ABSTRACTIONNALISATION DE LA LANGUE: PROBLÈMES SURVENANT DANS LA TRADUCTION DE TEXTES DE MÉTAPHYSIQUE RÉALISTE}

\section{Rés u mé}

Dans le processus de traduction des textes philosophiques, en particulier ceux concernant la métaphysique réaliste, en d'autres langues, apparaît une complication, qui finalement détermine le sens des mots et des phrases entières. Nous nous trouvons devant une triade concernant différents problèmes, à savoir : la standardisation du vocabulaire, l'abstractionnalisation des termes et la parcellarisation des fonctions du langage. La normalisation du langage se manifeste par le fait qu'au lieu de synonymes riches et diversifiés, apparaît un seul terme, avec lequel on veut exprimer divers processus et actions. A son tour, l'abstractionnalisation du langage consiste à fixer notre attention cognitive par le langage sur les termes et sur les concepts, et nous oriente à les analyser. Par contre, la parcellarisation des fonctions langagières revient à rompre l'unité de sa triple fonction (sémantique, syntaxique et pragmatique) et à se focaliser sur une seule d'entre elles: soit sémantique (concernant le sens), soit syntaxique (concernant la structure), soit pragmatique (concernant l'utilité).

La triade entière est directement liée à la traduction du texte métaphysique original en langues étrangères, et les problèmes qui en résultent ont été discutés dans l'article ci-dessus. Bien enten$\mathrm{du}$, ce sont des tendances linguistiques générales que nous rencontrons dans divers domaines. Cependant, dans le domaine des traductions du langage de la philosophie réaliste - c'est-à-dire de la métaphysique, qui a pour objet les choses réelles - le langage devrait guider la «vision» cognitive de ces choses réellement existantes.

Mots-clés : langage; métaphysique réaliste; traductions; standardisation du langage; abstractionnalisation du langage; fonctions du langage.

\section{OD STANDARYZACJI DO ABSTRAKCJONALIZACJI JĘZYKA: PROBLEMY JĘZYKOWE PRZY PRZEKŁADACH TEKSTÓW METAFIZYKI REALISTYCZNEJ}

\section{Streszczenie}

W ramach przekładów tekstów filozoficznych, a szczególnie tych z metafizyki realistycznej, na inne języki, pojawia się komplikacja, która w ostateczności rozstrzyga o znaczeniu słów, jak i o sensie całych zdań. Pojawia się triada, która nazwiemy problemową, a mianowicie: standaryzacja słownika, abstrakcjonalizacja terminów oraz parcelaryzacja funkcji języka. Standaryzacja języka przejawia się w tym, że w miejsce bogatych i różnorodnych synonimów pojawia się jeden termin, którym chce się oddać różnorodność procesów czy działań. Abstrakcjonalizacja języka z kolei polega na tym, że język zatrzymuje naszą uwagę poznawczą na terminach i pojęciach i nakierowuje nas na analizę tych terminów czy pojęć. Natomiast parcelaryzacja funkcji języka 
sprowadza się do rozbicia jedności jego potrójnej funkcji: semantycznej, syntaktycznej i pragmatycznej oraz koncentrowaniu się na jednej z nich: albo tylko semantycznej (znaczeniowej), albo tylko syntaktycznej (składniowej), albo tylko pragmatycznej (użytecznościowej).

Cała ta triada jest związana bezpośrednio z przekładami oryginalnego tekstu metafizycznego na języki obce, a problemy $\mathrm{z}$ tego wynikające zostały omówione w powyższym artykule. Oczywiście są to ogólne tendencje językowe, z którymi spotykamy się w rożnych dziedzinach. W dziedzinie jednak przekładów języka filozofii realistycznej - czyli metafizyki, która ma za przedmiot rzeczy realne - na ,widzenie” poznawcze tychże realnie istniejących rzeczy powinien naprowadzać język.

Słowa kluczowe: język; metafizyka realistyczna; przekłady; standaryzacja języka; abstrakcjonalizacja języka; funkcje języka. 


\section{ANNEX}

In the list below, yellow marks the words that were a problem in the discussion with the English translator of the publication: Karol Wojtyła, Considerations on the Essence of Man. Rozważania o istocie człowieka, transl. John Grondelski, Polskie Towarzystwo Tomasz z Akwinu, 2016. All words related to knowing, cognition, the object of cognition, the cognizing subject, etc. were expressed by the translator in English words: to know, knowing, known, which blur the difference between cognition as a process (cogniton, to cognize) and knowledge (knowledge, to know), which is the result of cognition.

\section{PODSTAWY NASZEJ WIEDZY O CZŁOWIEKU UWAGI WSTĘPNE}

\section{Postawa poznawcza}

Aby stworzyć pewny grunt dla naszych rozważań na temat człowieka i jego natury, wypada rozpocząć od ścisłego określenia zasad, którymi kierujemy się w naszym myśleniu i poznawaniu. Takie określenie potrzebne jest również w tym celu, aby uchwycić tę prawidłowość, z jaką wyprowadzamy nasze wnioski w oznaczonej dziedzinie.

a) Ta postawa poznawcza, którą przyjmujemy, przystępując do interpretacji całej rzeczywistości i każdego jej odcinka, jest na wskroś realistyczna. Zakładamy tedy, że umysł nasz dosięga pozaumysłowej rzeczywistości i zdolen jest ujmować samą jej istotę. Takie nastawienie odróżnia nas od wszelkiego rodzaju agnostyków czy też idealistów, którzy obrazu świata nie wydobywają z przedmiotowej rzeczywistości, ale uznają go za czysty wytwór myślącego podmiotu.

b) W konsekwencji taka postawa poznawcza zwrócona jest ku przedmiotowej rzeczywistości, którą ujmuje i tłumaczy - stąd jest ona obiektywistyczna. Podmiotem poznającym interesuje się między innymi jako narzędziem poznania, nie zaś jako źródłem poznania.

c) Liczymy się z bogatym zasięgiem możliwości poznawczych rozumu ludzkiego. Określamy ten zasięg, stwierdzając, że przedmiotem właściwym jego poznawania jest

\section{THE BASES OF OUR KNOWLEDGE ABOUT MAN INTRODUCTORY REMARKS}

\section{Cognitive Attitude}

In order to lay a solid base for our considerations about man and his nature, we should begin with a precise definition of the principles guiding our thinking and cognizing. Such definition is also needed for the purpose of capturing the accuracy of how we reach our conclusions in a given field.

a) The cognitive attitude that we take in turning to an interpretation of the whole of reality and its parts is realistic in a thoroughgoing way. We therefore posit that our mind attains to extra-mental realities and is capable of grasping their essence. Such a an attitude differentiates us from every sort of agnostics or even idealists, who do not derive their image of the world from objective reality but treat it as a pure creation of the thinking subject.

b) That cognitive attitude is consequently turned towards objective reality, which it understands and explains and is thus objectivistic. Such a an attitude is interested in the cognizing subject object as, among other things, a tool of knowing, not as a source of cognition.

c) We reckon with the rich range of human reason's possibilities of cogniton. We demarcate that range in saying that its proper object of cogniton is every being, i.e., everything that 
wszelki byt, tzn. wszystko, co w jakikolwiek sposób istnieje lub istnieć może. Oczywiście taki jest zasięg możliwości - gdy chodzi o aktualne poznanie, a obejmuje ono zawsze tylko pewien wycinek rzeczywistości bytującej. W każdym razie w tej rzeczywistości poznanie nasze odkrywa wielość bytów (pluralizm), nie zaś wiele przejawów jakiegoś jednego bytu (monizm). Jest to wniosek, który narzuca się nam już $\mathrm{w}$ drodze prostego przednaukowego doświadczenia.

d) Jeżeli jedynie słusznym punktem wyjścia w określeniu tej naszej postawy poznawczej jest realizm, to termin ów oznacza nie tylko, że rozum nasz dosięga rzeczy samych w sobie oznacza on również, że - logicznie - pierwszym przedmiotem naszego poznania są rzeczy, czyli byty. Dalszym dopiero krokiem będzie interpretacja tej przedmiotowej rzeczywistości bytującej. Taką interpretację stanowi materializm, taką też interpretację stanowi dualizm, tzn. pogląd wyróżniający w obrębie poznawanej przez nas rzeczywistości dwoisty rodzaj bytów: ducha i materię. Jakkolwiek tedy nasze poznanie spotyka się przez zmysły w pierwszej linii z bytami materialnymi otaczającego nas świata, to jednak niesłuszną jest rzeczą twierdzić, że przedmiotem właściwym i zupełnym naszego poznania jest materia. Jest nim po prostu byt lub raczej są nim byty w całym swym bogactwie i różnorodności. Zagadnienie: czy te byty są materią, czy też owym innym od materii wewnętrznie niezależnym ustrojem, który my nazywamy „duchem”, to już kwestia interpretacji opartej na wnikliwym i powolnym badaniu rzeczywistości poznawanej.

Kluczową pozycję (i to zupełnie dosłownie - kluczową) w badaniu i w interpretacji tej rzeczywistości zajmuje człowiek. in some way exists or can exist. That is, of course, the range of possibilities: as far as actual cogniton is concerned, it always encompasses but a certain part of existing reality. In any event, our cogniton discovers a plurality of being (pluralism) in that reality, not multiple manifestations of some single being (monism). This is a conclusion which forces itself upon us already on the path of simple, pre-academic experience.

d) If realism is the one proper point of departure to define our cognitive attitude, [then] that term means not only that reason can attain to things in themselves but also that things, i.e., beings, are logically the first objects of our cognition. The interpretation of that objective and existing reality is a subsequent step. Materialism constitutes such an interpretation. So, too, does dualism, i.e., the view that differentiates two kinds of being - spirit and matterwithin the reality that we come to know. Although, then, our cognition at first encounters the material beings of the world which surrounds us through the senses, it would be wrong to claim that the total and proper object of our cognition is matter. That object is simply being or, rather, beings in their whole richness and diversity. The question: whether these beings are matter or have an independent internal structure different from matter, which we call "spirit," is the interpretive question that is based on a thorough and careful study of the cognized realities.

It is man who occupies the key position (and that is completely literal - the key one) in the study and interpretation of that reality. 